\title{
Antioxidant activity and combination characteristics of filtrates and sargassum polycystum seaweed salt residue
}

\author{
Nurjanah*, Asadatun Abdullah, Amalia Rahmadhani, Anggrei Viona Seulalae \\ Dept. of Aquatic Product Technology, Faculty of Fisheries and Marine Sciences, \\ IPB University (Bogor Agricultural University), Dramaga Campus of IPB, \\ Agatis Street, Bogor 16680 West Java, Indonesia \\ *Corresponding author: nurjanah@apps.ipb.ac.id
}

\begin{abstract}
Sargassum polycystum is a low-sodium salt raw material that meets the dietary salt criteria, i.e., low $\mathrm{Na}$ : $\mathrm{K}$ ratio and $\mathrm{NaCl}$ content $<60 \%$. This study aims to produce seaweed salt with high yield, dietary fiber content, and antioxidant activity according to the quality standard of dietary salt through a combination of the filtrate and salt extraction residue. The results showed that the produced $S$. polycystum brown seaweed salt had a mineral Na $96.97 \mathrm{mg} / \mathrm{g}$ and mineral K $247.59 \mathrm{mg} / \mathrm{g}$. Na: $\mathrm{K}$ ratio of $0.39, \mathrm{NaCl}$ content of $49.05 \%$, and heavy metal residue below the Indonesian National Standard maximum standard for dietary salt. The levels of dietary fiber produced in salt samples $1: 1,1: 2$, and $2: 1$ was $34.41 \%, 40.16 \%$, and $23.83 \%$, respectively, and the iodine content (KIO3) of the control salt was $125.95 \mathrm{mg} / \mathrm{kg}$. The antioxidant activity of seaweed salt 2,2-diphenyl-1-picryl-hydrazyl-hydrate (DPPH) on salt K (seaweed salt without residue), residue, S1 (1:1), S2 (1:2), and S3 (2:1) was 26.41 ppm, $59.06 \mathrm{ppm}, 12.29 \mathrm{ppm}, 67.30 \mathrm{ppm}$, and $87.50 \mathrm{ppm}$. Meanwhile, the antioxidant capacity of seaweed salt Cupric Reducing Antioxidant Capacity (CUPRAC) on K salt, residue, S1, S2, and S3 were 12.36, 19, 7.86, 8.52 and $12.27 \mu \mathrm{mol}$ ascorbic acid/g extract, respectively. Therefore, it was concluded that increasing the yield and dietary fiber content in the seaweed salt production process is achievable by adding residues.
\end{abstract}

Keywords: Dietary fiber; $\mathrm{NaCl}$; $\mathrm{NaK}$ ratio; Sargassum polycystum; seaweed salt

\section{Introduction}

Seaweed is a macroalga that generally lives in marine habitats and is also a multicellular species with no distinct roots, stems, or leaves. Therefore, it has a thalloid, which functions like roots and stems (Baweja et al., 2016). Seaweed has been used as food by humans, and humans evolved by foraging in coastal areas. It contains essential elements with various benefits, such as minerals, vitamins, omega-3, taurine, and iodine (Mouritsen et al., 2018). Furthermore, it produces several bioactive components, including polysaccharides and pigments, as well as secondary metabolites such as alkaloids, phenols, flavonoids, saponins, steroids, and terpenoids (Perez et al., 2016; Diachanty et al., 2017; Gazali et al., 2019a; Gazali et al., 2019b). In Asian cultures, especially in Japan, China, and Korea, seaweed is commonly consumed in soups, sushi, salads, snacks, and other dishes. Over the past few years, seaweed has entered the global food market and has been considered a healthy food (Aakre et al., 2020). Seaweed is generally classified into three divisions, namely green 
seaweed (Chlorophyta), red seaweed (Rhodophyta), and brown seaweed (Phaeophyta) (Asmida et al., 2017).

Brown seaweed (Phaeophyta) has more than 1500 species in the world. The brown color of the seaweed is caused by carotenoid and fucoxanthin pigments (Ali et al., 2017). Brown seaweed has a high mineral content that humans can consume. Brown seaweed also contains carotenoids, laminarin, alginate, fucoidan, and phlorotannin and contains phenolic compounds as a source of antioxidants (Bono et al., 2014). Brown seaweed is also an abundant and renewable source of polysaccharides. Its polysaccharides have exciting structures and physiological activities (Li et al., 2019). Seaweed has been developed in the cosmetics field (Nurjanah et al., 2016), likely sunscreens (Nurjanah et al., 2017; Nurjanah et al., 2019a; Nurjanah et al., 2019b), peel off masks (Nurjanah et al., 2019c); lightening (Sari et al., 2019; Dolorosa et al., 2019; Dolorosa et al., 2017), lip balm (Nurjanah et al., 2018a), acne mask (Nurjanah et al., 2018b), body lotion (Nurjanah et al., 2020a; Nurjanah et al., 2021).

Hypertension increases systolic and diastolic blood pressure that exceeds the standard limit, namely systolic blood pressure of $140 \mathrm{mmHg}$ or diastolic blood pressure of $90 \mathrm{mmHg}$. Based on WHO (2013), a hypertensive disease is a group of non-communicable conditions that cause death by killing 63 million people per year. WHO (2015) also shows that the prevalence of hypertension globally reaches 1.13 billion individuals, which means that 1 in 3 people is indicated as having hypertension. Internal and external factors influence hypertension-internal factors such as heredity, race, and gender. External factors are alcohol, cigarettes, stress, overweight, and excessive salt consumption (Khehr \& Makker, 1992).

Excessive salt consumption is one factor that is considered to have a high risk for people with hypertension. However, several studies have shown that reducing salt intake can reduce systolic blood pressure by an average of 3-5 $\mathrm{mmHg}$, with a more significant effect in older people with severe hypertension (Mahan et al., 1997). Therefore, the effort to be made is to replace regular salt intake with low sodium and high potassium salt. Seaweed salt is a low sodium salt product $(\mathrm{NaCl}<60 \%)$ that is claimed to help keep the blood pressure of hypertensive patients in average condition. Making salt from seaweed is one way to utilize natural ingredients that have antioxidant and mineral activity and can produce low sodium salt (Nufus et al., 2019; Kurniawan et al., 2019; Nurjanah et al., 2020b; Nurjanah et al., 2020c; Nurjanah et al., 2018c).

The utilization of residues produced in seaweed salt is expected to add chemical and mineral components to the seaweed salt product itself. This research was conducted by making seaweed salt from a combination of filtrate and salt extraction residue to increase the yield of seaweed salt produced. Residual reuse is an effort to implement regulations on zero waste so that the raw materials are free of garbage because all materials are reused. The addition of residue also aims to increase dietary fiber content in the seaweed salt. Based on Marquez et al. (2016) research, a high-fiber diet and acetate supplementation significantly reduced systolic and diastolic blood pressure, cardiac fibrosis, and left ventricular hypertrophy. Acetate has a similar effect and markedly reduces renal fibrosis. Therefore, this study aims to produce seaweed salt with a high yield and contain dietary fiber that meets dietary salt quality standards through a filtrate and salt extraction residue. 


\section{Materials and method}

2.1 Making of Seaweed Salt (Magnusson et al., 2016 with modification)

The primary raw material for making seaweed salt from Sargassum polycystum is the seaweed that has become flour. The process of making seaweed flour is that seaweed is dried using a dehydrator at a temperature of $40-50^{\circ} \mathrm{C}$ for $4-5$ hours. The following method is that the seaweed is mashed using a blender to become seaweed flour. First, seaweed flour of $70 \mathrm{~g}$ was added to distilled water at a concentration of 1:10. Next, the mixture was heated in a water bath at $40^{\circ} \mathrm{C}$ for 10 minutes. Mixtures were then filtered using a cloth filter with a size of $500 \mu \mathrm{m}$. The filtrate from the first filtering procedure was filtered again using Whatman 42 filter paper and subsequently poured into a baking sheet and dried using an electric oven at a temperature of $60^{\circ} \mathrm{C}$ for 30 hours. Furthermore, the residue from the first filtering procedure was dried using an electric oven at a temperature of $60^{\circ} \mathrm{C}$ for 30 hours. Finally, the salt from the residual filtrate was mixed in a ratio of 1:1 (S1), 1:2 (S2), and 2:1 (S3) (Magnusson et al., 2016).

\subsection{Yield Analysis (AOAC 2005)}

The yield value was generated from the total seaweed salt produced ratio and the number of raw materials used. Finally, the yield calculation was carried out to determine the percentage of seaweed salt obtained.

Extract yield $(\%)=\quad \frac{\text { extract weight }(g)}{\text { raw material weight }(g)} \quad \frac{\text { extract weight }(g)}{\text { raw material weight }(g)} \times 100 \%$

Salt yield $(\%)=\quad \frac{\text { salt weight }(g)}{\text { flour weight }(g)} \quad \mathrm{X} 100 \%$

\subsection{Analysis of Mineral Composition (AOAC 2011)}

Seaweed salt sample preparation started with weighing 0.5-1 gram of the sample into an Erlenmeyer. Furthermore, $10 \mathrm{~mL}$ of concentrated HNO3 was added, and the vessel was closed and placed in microwave digestion (Ramp to $150^{\circ} \mathrm{C}$ for 10 minutes and Hold at $150^{\circ} \mathrm{C}$ for 15 minutes). The digestion results were transferred to a $50 \mathrm{~mL}$ volumetric flask and $100 \mathrm{mg} / \mathrm{L}$ internal standard Yttrium of $0.50 \mathrm{~mL}$. Subsequently, dilution was carried out with aquabidest until the mixture was homogenized. The solution was further filtered using filter paper Whatman no 42 sizes $2.5 \mu \mathrm{m}$, and the sample solution was measured in the Inductively Coupled Plasma-Optical Emission Spectrometry (ICP OES) system.

The mineral contents of $S$. polycystum seaweed, which consisted of sodium $(\mathrm{Na})$, potassium $(\mathrm{K})$, calcium $(\mathrm{Ca})$, iron $(\mathrm{Fe})$, and magnesium $(\mathrm{Mg})$, were carried out by the AOAC method (2011) using ICP OES. Furthermore, the wavelengths used were $568,821 \mathrm{~nm}$, 766,491nm, 317,933nm, 238,204nm, and 285,213nm for Na, K, Ca, Fe, and Mg. 


\subsection{Analysis of Heavy Metal Contaminants (AOAC 2011)}

Sample preparation was carried out similarly for mineral analysis. The heavy metals analyzed in $S$. polycystum salt include $\mathrm{Hg}, \mathrm{Pb}$, and $\mathrm{Cd}$ by the AOAC method (2011) using ICP OES. The wavelengths used for each heavy metal were $220,353 \mathrm{~nm}, 184,887 \mathrm{~nm}$, and $214,439 \mathrm{~nm}$ for $\mathrm{Pb}, \mathrm{Hg}$, and $\mathrm{Cd}$, respectively.

\subsection{Analysis of $\mathrm{NaCl}$ Content (SNI 3556:2016)}

The principle for the analysis of $\mathrm{NaCl}$ content is a titration with silver nitrate. $5 \mathrm{~g}$ of the sample was ashed in a furnace at $550^{\circ} \mathrm{C}$ until complete ashing for 3-4 hours was done. Furthermore, the cooling process was carried out at room temperature. The ash was dissolved with hot distilled water, placed into a $50 \mathrm{~mL}$ volumetric flask, and homogenized. The solution formed was filtered with a filter paper, after which $5 \mathrm{~mL}$ of the filtrate was pipetted into a $100 \mathrm{~mL}$ Erlenmeyer. Finally, $10 \mathrm{~mL}$ of distilled water was added, homogenized, and the $\mathrm{pH}$ of the solution was checked. The $\mathrm{K}_{2} \mathrm{CrO}_{4}$ indicator was added and titrated with a standard solution of $\mathrm{AgNO}_{3} 0.1 \mathrm{~N}$ until the precipitate was brick red.

\subsection{Analysis of Dietary Fiber Content}

To carry out this analysis, 0.5 - 1 gram of the sample was placed in a $400 \mathrm{~mL}$ beaker, and $40 \mathrm{~mL}$ of MES-TRIS buffer was added. The mixture was stirred until there were no clumps in the sample. Furthermore, $50 \mu \mathrm{L}$ of the $\alpha$-amylase enzyme was added, stirred until homogeneous, covered with aluminum foil, and incubated in a water bath shaker at $100^{\circ} \mathrm{C}$ for 30 minutes. The solution was heated at $60^{\circ} \mathrm{C}$, and a gel was formed on the beaker, which was broken down with a spatula, after which the spatula and glass walls were rinsed with $10 \mathrm{~mL}$ of distilled water. Next, $100 \mu \mathrm{L}$ of the protease enzyme was added to the solution, stirred, and covered again with aluminum foil. Incubation was conducted in a water bath shaker at $60^{\circ} \mathrm{C}$ for 30 minutes. Finally, $5 \mathrm{~mL}$ of $0.561 \mathrm{M} \mathrm{HCl}$ was further added, and the $\mathrm{pH}$ of the sample was adjusted to $4.1-4.6$ with either $1 \mathrm{M} \mathrm{NaOH}$ or $1 \mathrm{M} \mathrm{HCl}$ solution. Subsequently, $200 \mu \mathrm{L}$ of amyloglucosidase enzyme was added, stirred until homogeneous, and incubated at $60^{\circ} \mathrm{C}$ for another 30 minutes. The next step was the addition of $225 \mathrm{~mL}$ of $95 \%\left(60^{\circ} \mathrm{C}\right)$ ethanol, which was stirred until homogeneous. The solution was left for 1 hour, filtered, and washed with $2 \times 15 \mathrm{~mL}$ of $78 \%$ ethanol, $95 \%$ ethanol, and acetone. The filter paper was oven-dried at a temperature of $103 \pm 2{ }^{\circ} \mathrm{C}$, filtered with a filter paper containing the weighed residue, and the ash weight in the first residue and protein weight in the second residue were determined.

\subsection{Analysis of Iodine Content ( $\left.\mathrm{KIO}_{3}\right)$ (SNI 3556:2016)}

To carry out this analysis, 25 grams of the sample was placed in a $250 \mathrm{~mL}$ Erlenmeyer and dissolved with $50 \mathrm{~mL}$ of distilled water. Furthermore, $2 \mathrm{~mL}$ of $2 \mathrm{~N} \mathrm{H}_{2} \mathrm{SO}_{4}$ and $5 \mathrm{~mL}$ of $10 \% \mathrm{KI}$ solution were added. Next, the sample was placed in a dark room for 10 minutes, after which it was titrated with $0.005 \mathrm{~N} \mathrm{Na}_{2} \mathrm{~S}_{2} \mathrm{O}_{3} .5 \mathrm{H}_{2} \mathrm{O}$ until light yellow, and $2 \mathrm{~mL}$ of $1 \%$ starch solution was subsequently added. Lastly, the titration was repeated with $\mathrm{Na}_{2} \mathrm{~S}_{2} \mathrm{O}_{3} .5 \mathrm{H}_{2} \mathrm{O} 0.005 \mathrm{~N}$ until a color change from dark blue to colorless (clear) was observed. 


\subsection{Antioxidants}

\subsubsection{DPPH method (Molyneux, 2004).}

Antioxidant activity testing was carried out at several concentrations of seaweed salt samples, namely $10,20,30,40$, and $50 \mathrm{ppm}$. The sample solution was prepared by reacting $4.5 \mathrm{~mL}$ of a sample with $0.5 \mathrm{~mL}$ of DPPH. Furthermore, a blank solution was prepared by reacting $4.5 \mathrm{~mL}$ of ethanol PA with $0.5 \mathrm{~mL}$ of DPPH. The mixture was incubated in a dark room at room temperature for 30 minutes, after which the absorbance was measured using a spectrophotometer at a wavelength of $517 \mathrm{~nm}$. Vitamin $\mathrm{C}$ (ascorbic acid) was made in concentrations of $1,2,3,4$, and 5 ppm and used as a positive control.

Radical binder $(\%)=\frac{\text { blank absorbance }- \text { sample absorbance }}{\text { blank absorbance }} \times 100 \%$

\subsubsection{CUPRAC method (Apak et al., 2007).}

Testing the antioxidant activity of seaweed salt using the CUPRAC method by mixing $0.3 \mathrm{~mL}$ of a sample with $1 \mathrm{~mL}$ of $0.01 \mathrm{M} \mathrm{CuCl}_{2} .2 \mathrm{H}_{2} \mathrm{O}, 1 \mathrm{~mL}$ of $0.0075 \mathrm{M}$ ethanolic neucoprine, $1 \mathrm{~mL}$ of ammonium acetate buffer $\mathrm{pH} 7$ and $0.8 \mathrm{~mL}$ of distilled water. The sample and reagent mixture was homogenized using vortex and in a dark room at room temperature for 30 minutes. Furthermore, the absorbance was measured at a wavelength of $450 \mathrm{~nm}$ using Ultraviolet-visible (UV-Vis) spectrophotometer. In addition, standard curves used ascorbic acid with concentrations of $1,2,3,4$, and 5 ppm.

\section{Results}

\subsection{Yield of Seaweed Salt}

Yield analysis of seaweed salt was carried out to determine the weight of the produced salt. In previous studies, 9 grams of seaweed salt was made from 70 grams of $S$. polycystum seaweed flour, and the yield was $12.86 \%$.

\subsection{Mineral Composition of Seaweed Salt}

$S$. polycystum brown seaweed has an excellent ability to absorb minerals; therefore, it has quite various mineral levels. The results of the mineral composition of seaweed salts are presented in (Table 1). The minerals analyzed include $\mathrm{Na}, \mathrm{K}, \mathrm{Ca}, \mathrm{F}$ and $\mathrm{Mg}$.

Table 1. Mineral composition of seaweed salt

\begin{tabular}{|l|c|c|c|c|c|}
\hline \multicolumn{1}{|c|}{ Sample } & $\mathrm{Na}(\mathrm{mg} / \mathrm{g})$ & $\mathrm{K}(\mathrm{mg} / \mathrm{g})$ & $\mathrm{Ca}(\mathrm{mg} / \mathrm{g})$ & $\mathrm{Fe}(\mathrm{mg} / \mathrm{g})$ & $\mathrm{Mg}(\mathrm{mg} / \mathrm{g})$ \\
\hline Salt K & $96.97 \pm 2.21$ & $247.59 \pm 3.90$ & $6.42 \pm 0.18$ & $0.07 \pm 0$ & $16.44 \pm 0.30$ \\
\hline Salt S1 & $49.11 \pm 0.08$ & $192.66 \pm 0.57$ & $12.25 \pm 0.48$ & $0.12 \pm 0$ & $15.49 \pm 0.16$ \\
\hline Salt S2 & $33.10 \pm 0.06$ & $136.42 \pm 0.91$ & $14.28 \pm 0.13$ & $1.74 \pm 0.01$ & $14.33 \pm 0.04$ \\
\hline Salt S3 & $53.01 \pm 0.18$ & $200.47 \pm 0.42$ & $9.40 \pm 0.01$ & $0.12 \pm 0$ & $17.40 \pm 0.02$ \\
\hline
\end{tabular}

Note : Salt K (seaweed salt control without residue); Salt S1 (1 seaweed salt: 1 residue ); Salt S2 (1 seaweed salt: 2 residues); Salt $\mathrm{S} 3$ (2 seaweed salt: 1 residue) 


\subsection{Na:K Ratio, NaCl Content, Dietary Fiber Content of Seaweed Salt}

The $\mathrm{Na}$ : $\mathrm{K}$ ratio and $\mathrm{NaCl}$ content are essential parameters for applying dietary salt to hypertensive patients. The Na: $\mathrm{K}$ ratio results were obtained by dividing the mineral $\mathrm{Na}$ value by that of K. Furthermore, dietary fiber is an essential component in food for maintaining the health and function of the digestive system. The $\mathrm{Na}$ : $\mathrm{K}$ ratio, $\mathrm{NaCl}$, and dietary fiber content values are presented in (Table 2).

Table 2. Na: K Ratio, $\mathrm{NaCl}$, and dietary fiber of seaweed salt

\begin{tabular}{|l|c|c|c|c|c|}
\hline Sample & $\mathrm{Na}(\mathrm{mg} / \mathrm{g})$ & $\mathrm{K}(\mathrm{mg} / \mathrm{g})$ & $\mathrm{Na}$ K Ratio & $\mathrm{NaCl}(\%)$ & Dietary Fiber (\%) \\
\hline Salt K & $96.97 \pm 2.21$ & $247.59 \pm 3.90$ & $0.39 \pm 0$ & $49.05 \pm 0.07$ & - \\
\hline Salt S1 & $49.11 \pm 0.08$ & $192.66 \pm 0.57$ & $0.26 \pm 0.01$ & $26.45 \pm 0.12$ & $34.41 \pm 0.09$ \\
\hline Salt S2 & $33.10 \pm 0.06$ & $136.42 \pm 0.91$ & $0.24 \pm 0$ & $20.88 \pm 0.68$ & $40.16 \pm 0.23$ \\
\hline Salt S3 & $53.01 \pm 0.18$ & $200.47 \pm 0.42$ & $0.26 \pm 0$ & $39.25 \pm 0.13$ & $23.83 \pm 0.16$ \\
\hline
\end{tabular}

Description:

- $\quad=$ not tested

\subsection{Heavy Metal Contaminants of Seaweed Salt}

This analysis was carried out to determine the number of heavy metal contaminants present in seaweed salt, one of the parameters for salt consumption. The heavy metals tested include mercury $(\mathrm{Hg})$, lead $(\mathrm{Pb})$, and cadmium $(\mathrm{Cd})$, and the results are shown in (Table 3$)$.

Table 3. Heavy metal contaminants of seaweed salt

\begin{tabular}{|l|c|c|c|c|c|}
\hline Parameter & $\begin{array}{c}\text { Salt K } \\
(\mathrm{mg} / \mathrm{kg})\end{array}$ & $\begin{array}{c}\text { Salt S1 } \\
(\mathrm{mg} / \mathrm{kg})\end{array}$ & $\begin{array}{c}\text { Salt S2 } \\
(\mathrm{mg} / \mathrm{kg})\end{array}$ & $\begin{array}{c}\text { Salt S3 } \\
(\mathrm{mg} / \mathrm{kg})\end{array}$ & $\begin{array}{c}\text { BSN (2016) } \\
(\mathrm{mg} / \mathrm{kg})\end{array}$ \\
\hline $\mathrm{Hg}$ & Not detected & $0.04 \pm 0$ & $0.04 \pm 0$ & $0.04 \pm 0$ & Max 0.1 \\
\hline $\mathrm{Pb}$ & Not detected & $0.56 \pm 0$ & $0.69 \pm 0.01$ & $0.56 \pm 0$ & Max 10.0 \\
\hline $\mathrm{Cd}$ & $0.18 \pm 0.01$ & $0.51 \pm 0.01$ & 0.560 & $0.51 \pm 0$ & Max 0.5 \\
\hline
\end{tabular}

3.5 Iodine Content (KIO3) of Seaweed Salt

Apart from $\mathrm{NaCl}$ content, the salt requirement which may be used as dietary salt is iodine content. Potassium iodate (KIO3) is iodine in the form of salt, an essential ingredient for thyroid hormone synthesis. The thyroid hormone plays a vital role in regulating the body's metabolism. Iodine is mainly sourced from fish, shellfish, and seaweed (Gibney et al., 2009). The result of seaweed salt iodine content in this study was $212.22 \pm 1.70 \mathrm{mg} / \mathrm{kg}$. Meanwhile, the minimum iodine (KIO3) range in dietary salt is $30 \mathrm{mg} / \mathrm{kg}$ (BSN 2016).

\subsection{Antioxidant of Seaweed Salt}

Measurement of antioxidant activity and capacity using the DPPH and CUPRAC method was carried out on flour, residue, salt $\mathrm{K}, \mathrm{S} 1, \mathrm{~S} 2$, and S3. This measurement was carried out to 
determine the antioxidant activity and capacity of the resulting seaweed salt. The antioxidant activity of seaweed salts is shown in (Table 4).

Table 4. Antioxidants of seaweed salt

\begin{tabular}{|c|c|c|}
\hline Sample & $\mathrm{DPPH} \mathrm{IC}_{50}$ antioxidant activity (ppm) & $\begin{array}{c}\text { CUPRAC antioxidant capacity } \\
(\mu \mathrm{mol} \text { ascorbic acid/g) }\end{array}$ \\
\hline Salt K & $25.59 \pm 1.17$ & $18.58 \pm 0.59$ \\
\hline Residue & $58.66 \pm 0.56$ & $11.77 \pm 0.83$ \\
\hline Salt S1 & $13.41 \pm 1.58$ & $7.43 \pm 0.61$ \\
\hline Salt S2 & $66.69 \pm 0.87$ & $8.91 \pm 0.55$ \\
\hline Salt S3 & $85.01 \pm 3.53$ & $12.17 \pm 0.15$ \\
\hline
\end{tabular}

Note: The IC50 value is the concentration of the sample that can capture DPPH radicals as much as $50 \%$ of the initial concentration.

\section{Discussion}

The heating process was further carried out at a temperature of $40^{\circ} \mathrm{C}$ for 10 minutes, with a solvent ratio of $1: 10$ and oven temperature of $60^{\circ} \mathrm{C}$ for 30 hours. Research by Nurjanah et al. (2020) showed that the average yield of seaweed salts of Turbinaria conoides and Padina minor ranged from $20 \%-26 \%$ at $40^{\circ} \mathrm{C}$ and $55^{\circ} \mathrm{C}$ and time (10 and 30 minutes). The difference in yield was due to some factors, such as different sampling locations. In the study by Nurjanah et al. (2020), seaweed was obtained from Scout Island in Thousand Island Regions, Indonesia. In this study, the sample was obtained from Carita Beach, Banten, West Java, Indonesia. The yield, which was slightly improved with the addition of the residue, increased the benefit from the other contents of the residue.

The mineral composition of the residue tends to decrease; this is presumably due to the salt extraction process; the minerals contained in the seaweed dissolve in the filtrate so that the minerals that settle on the residue tend to decrease.

The process of making salt with heat led to its concentration; therefore, the mineral composition increased compared to being in the flour state (Magnusson et al., 2016). The sodium $(\mathrm{Na})$ and potassium $(\mathrm{K})$ content were the highest in composition compared to other minerals, which decreased with the addition of residue to the seaweed salt. The results showed that the residual mineral content yielded lower $\mathrm{Na}$ and $\mathrm{K}$ levels than flour. Therefore, one of the causes of $\mathrm{Na}$ and $\mathrm{K}$ levels is reducing seaweed salt. Meanwhile, salt $\mathrm{K}$ with $100 \%$ salt filtrate had higher $\mathrm{Na}$ and $\mathrm{K}$ content.

Potassium is an essential mineral that plays a significant role in maintaining the cells' resting membrane potential and intracellular osmolarity (Ekmekcioglu et al., 2015). Sodium functions to maintain fluid, osmotic, and acid-base balance (Venugopal, 2008). The increased intake of magnesium and potassium coupled with reduced sodium intake is more effective in lowering blood pressure than single mineral intake. It is often as effective as one 
antihypertensive drug in treating hypertension (Houston, 2011). Calcium is also vital in regulating blood pressure by helping the muscles in the walls of blood vessels to contract. This magnesium and calcium duet work help maintain a normal heart rhythm by relaxing and contracting the heart muscle (Mahan and Escott-Stump, 2008). Iron is an essential element for almost all living organisms as it participates in a wide variety of metabolic processes, including oxygen transport, deoxyribonucleic acid (DNA) synthesis, and electron transport (Abbaspour et al., 2014). Factors that affect the number of minerals in seaweed are the amount of variation in the number of minerals and organic components on the bottom of the water, the nature of the depth of the waters, the distance from the soil and the environment, and their habitat (Venugophal, 2008).

The Na: K ratio obtained from salt K, S1, S2, and S3 was $0.39,0.26,0.24$, and 0.26 . The result follows the established ideal ratio, which is 0.3 - 1, according to (WHO 2012). Flour, residue, salt K, S1, and S3 are in accordance with the applicable standards; however, salt $\mathrm{S} 2$ did not attain the ideal Na: $\mathrm{K}$ ratio. This was due to the addition of residue, which reduced the $\mathrm{Na}$ and $\mathrm{K}$ mineral contents. The consumption of potassium increases its concentration in the intracellular fluid, consequently drawing fluid from the extracellular region and lowering blood pressure. Therefore, the potassium ratio to sodium in the diet plays a role in preventing and controlling hypertension (Perez \& Chang, 2014).

The antioxidant activity in several samples of seaweed salt showed intense to extreme $\mathrm{IC}_{50}$ values. Salt $\mathrm{S} 1$ had an antioxidant activity of $13.41 \mathrm{ppm}$ and was included in the powerful antioxidant category. Furthermore, salt S3 had an antioxidant activity of $85.01 \mathrm{ppm}$ and was included in the strong antioxidant category. Meanwhile, the antioxidant activity of the control salt, residue, and salt S2 was 25.59 ppm (very strong), $58.66 \mathrm{ppm}$ (strong), and $66.69 \mathrm{ppm}$ (strong), respectively. Based on a study by BSN (2016), the S. polycystum seaweed salt had an $\mathrm{IC}_{50}$ value of $77 \mathrm{mg} / \mathrm{L}$, which was included in the strong antioxidant category. The residue of $S$. polycystum contained several bioactive compounds such as alkaloids, saponins, and steroids (Auliya, 2019), which also affect the antioxidant activity of seaweed salt.

Bioactive compounds affect the antioxidant content, such as phlorotannins derived from marine brown algae have strong antioxidant activities on free radicals ( $\mathrm{Li}$ and Kim, 2011). The activity of reducing free radicals in the DPPH method is dependent on the $\mathrm{IC}_{50}$ value (inhibitory concentration). This value represents the concentration of the test compound that causes a $50 \%$ loss of free radical activity. This implies that the $\mathrm{IC}_{50}$ and antioxidant activity are inverse, where the smaller the $\mathrm{IC}_{50}$ value, the higher the antioxidant activity (Komala et al., 2015).

Meanwhile, the antioxidant capacity of some seaweed salt samples using the CUPRAC method tends to be small. The study by BSN (2016) showed that the S. polycystum seaweed salt had an IC50 value of $107.76 \mu \mathrm{mol}$ trolox/g, a small capacity. The highest salt antioxidant capacity of $18.58 \mu \mathrm{mol}$ ascorbic acid/g was found in salt $\mathrm{K}$, while the lowest value of $7.43 \mu \mathrm{mol}$ ascorbic acid/g was found in salt S1. Meanwhile, the antioxidant capabilities of 
the residues, salts $\mathrm{S} 2$, and $\mathrm{S} 3$, were $11.77 \mu \mathrm{mol}$ ascorbic acid/g, $8.91 \mu \mathrm{mol}$ ascorbic acid/g, and $12.17 \mu \mathrm{mol}$ ascorbic $\mathrm{acid} / \mathrm{g}$, respectively.

Determination of antioxidant activity with the CUPRAC method was determined using bis (neocopyrine) copper (II) compound as its chromogenic reagent. The CUPRAC method was used to determine the antioxidant activity with ascorbic acid as the standard (Apak et al., 2007). One cause of hypertension is increased oxidative stress (Ardalan and Kopaie 2014). Antioxidant compounds can stabilize free radicals, preventing chain reactions that may damage cells (Ross, 1999).

Sodium Chloride $(\mathrm{NaCl})$ is a complementary requirement and source of electrolytes for the human body. Its content in salt K, S1, S2 and S3 were 49.05\%, 26.45\%, 20.88\% and $39.25 \%$, respectively. These results follow the applicable dietary salt standards. The criteria for the ideal $\mathrm{NaCl}$ content as dietary salt for hypertensive patients is a maximum of $60 \%$ (BSN 2016). Excessive salt intake can affect health, especially blood pressure and kidneys (Malta et al., 2018).

Seaweed is a plant that has enough polysaccharide content, which makes it a potential source of proteins, vitamins, minerals, and dietary fiber (Penalver et al., 2020), with cellulose, hemicellulose, and lignin as its constituent. Dietary fiber intake is also associated with a reduced risk for the development of cardiovascular disease and mortality (Barber et al., 2020). The levels of dietary fiber in salt S1, S2, and S3 were $34.41 \%, 40.16 \%$, and $23.83 \%$, respectively. This increase was due to the addition of residue. Furthermore, it plays a role in reducing blood pressure by lowering cholesterol levels. This was because the heavy metals were not dissolved during the salt-making process at a temperature of $40^{\circ} \mathrm{C}$; therefore, the results of the filtrate that turned into salt were reduced by its contaminants. Furthermore, cadmium (Cd), which is classified as heavy metal with a high level of toxicity, was challenging to degrade; consequently, it stays for a long time in the water and later settles with the sediment (Wakida et al., 2008).

\section{Conclusion}

S. polycystum seaweed salt with additional treatment residue will help increase the salt yield. However, the addition of residue affected the level of dietary fiber in salt, which raised over time with residue. Therefore, the best treatment in this study was S2 (1:1), taking into account the parameters of the low $\mathrm{Na}$ : $\mathrm{K}$ ratio, levels of $\mathrm{NaCl}$, antioxidants, and the taste produced by the seaweed salt. $\mathrm{S} 1$ salt had a $\mathrm{Na}$ : $\mathrm{K}$ ratio of 0.26 , a $\mathrm{NaCl}$ content of $26.45 \%$, and had antioxidant activity classified as very strong with a value of IC50 amounted to $12.29 \mathrm{ppm}$ and antioxidant capacity of $7.86 \mu \mathrm{mol}$ ascorbic acid $/ \mathrm{g}$.

\section{ACKNOWLEDGMENTS}

The authors express gratitude to Prof. Dr. Ir Nurjanah, MS, for the PTUPT 1/E1/KP research grant.PTNBH/2021. 


\section{References}

Aakre, I., Evensen, L.T., Kjellevold, M., Dahl, L., Henjum, S., Alexander, J., Madsen, L., Markhus, M.W. (2020). Iodine status and thyroid function in a group of seaweed consumers in Norway. Nutrients. 12: 1-14.

Abbaspour, N., Hurrell, R., Kelishadi, R. (2014). Review on iron and its importance for human health. Journal of research in medical sciences: the official journal of Isfahan University of Medical Sciences. 19(2): 164-174.

Ali, A.Y.A., Idris, A.M., Ebrahim, A.M., Eltayeb, M.A.H. (2017). Brown algae (Phaeophyta) for monitoring heavy metals at the Sudanese red sea coast. Application Water Science. 7: 3817-3824.

Apak, R., Kubilay, G., Birsen, D., Mustafa, O., Saliha, E.C., Burcu, Berker, I.K., Dilek, O. (2007). Comparative evaluation of various total antioxidant capacity assay applied to phenolic compounds with the CUPRAC assay. Molecules.12:1496-1547.

Ardalan, M.R., \& Kopaie, M.R. (2014). Antioxidant supplementation in hypertension. Journal of Renal Injury Prevention. 3(2):39-40

Asmida, I., Akmal, A.B.N., Ahmad, I., Diyana, M.S. (2017). Biodiversity of macroalgae in Blue Lagoon, the Straits of Malacca, Malaysia and some aspects of changes in species composition. Sains Malaysiana. 46(1): 1-7.

Association of Analytical Chemist Publisher. (2005). Official methods of analysis of the association of official analytical chemist. Arlington Virginia USA: The Association of Official Analytical Chemist, Inc. Mayland. USA.

Association of Official Analytical Chemist. (2011). Official Method of Analysis of The Association of Official Analytical of Chemist. Arlington (US): The Association of Official Analytical Chemist, Inc.

Auliya, B.R. (2019). Karakteristik residu garam rumput laut coklat sebagai bahan baku sediaan body scrub [skripsi]. Bogor(ID): Institut Pertanian Bogor.

Badan Standarisasi Nasional. 2016. Garam diet. No. SNI 8208:2016. BSN. Jakarta. Standarisasi Nasional Indonesia.

Barber, T.M., Kabisch, S., Pfeiffer, A.F.H., Weickert, M.O. (2020). The health benefits of dietary fibre. Nutrients. $12: 3209$.

Baweja, P., Kumar, S., Sahoo, D., Levine, I. (2016). Seaweed in health and disease prevention chapter 3: biology of seaweed. Elsevier. 41-106.

Bono, A., Anisuzzaman, S., Ding, O. (2014). Effect of process condition on the gel viscosity and gel strength of semi-refined carrageenan (SRC) produced from seaweed (Kappaphycus alvarezii). Journal of King Saud University. 26(1): 3-9. 
Dolorosa, M. T., Nurjanah., Purwaningsih, S., Anwar, E. (2019). Utilization of Kappaphycus alvarezii and Sargassum plagyophyllum from Banten as cosmetic creams. In IOP Conference Series Earth and Environmental Science. https://iopscience.iop.org/article/10.1088/1755-1315/404/1/012008.

Ekmekcioglu, C., EImadfa, I., Meyer, A. L., Moeslinger, T. (2015). The role of dietary potassium in hypertension and diabetes. Journal of Physiology and Biochemistry. 72(1): 93106.

Gazali, M., Nurjanah., Zamani, N., P. (2019a). The screening of bioactive compound of the green algae Halimeda macroloba (Decaisne, 1841) as an antioxidant agent from Banyak Island Aceh Singkil. In IOP Conference Series Earth and Environmental Science. https://iopscience.iop.org/article/10.1088/1755-1315/348/1/012043.

Gazali, M., Zamani, N. P., Nurjanah. (2019b). The potency of green algae Chaetomorpha crassa Agardh as antioxidant agent from coastal of Lhok Bubon, West Aceh. In IOP Conference Series Earth and Environmental Science. https://iopscience.iop.org/article/10.1088/1755-1315/278/1/012029.

Gibney, J., Michael, Margetts, Barie, M., Kearney, John, M., Arab, L. (2009). Gizi Kesehatan Masyarakat, EGC, ID.

Houston, M. (2011). The role of magnesium in hypertension and cardiovascular disease. The Journal of Clinical Hypertension. 13(11): 843-847.

Indonesian National Standard. SNI 3556:2016. (2016). Iodized consumption salt. Jakarta (ID): National Standardization Agency.

Kher, K.K. \& Makker, S.P. (1992). Clinical Pediatric Nephrology. Singapore: McGrawHill International.

Komala, I., Azrifitria, Y., Betha, O.S., Muliati, F., Ni'mah, M. (2015). Antioxidant and anti-inflammatory activity of the Indonesian ferns Nephrolepis falcata and Pyrrosia lanceolata. International Journal of Pharmacy and Pharmaceutical Sciences. 7(12):76-87.

Kurniawan, R., Nurjanah, Jacoeb, A.M., Abdullah, A., Pertiwi, R.M. (2019). Characteristics of functional salt from green seaweed Ulva Lactuca. Indonesian Fisheries Processing Journal. 22(3):573-580. https://doi.org/10.17844/jphpi.v22i3.29320.

Li, J., Cai, C., Yang, C., Li, J., Sun, T., Yun, G. (2019). Recent advances in pharmaceutical potential of brown algal polysaccharides and their derivates. Current Pharmaceutical Design. 25: 1290-1311.

Li, Y. X., Kim, S. K. (2011). Utilization of seaweed-derived ingredients as potential antioxidants and functional ingredients in the food industry: An overview. Food Science and Biotechnology. 20(6):1461-1466. 
Magnusson, M., Carl, C., Mata, L., Nys, R., Paul, N.A. (2016). Seaweed salt from Ulva: a novel first step in a cascading biorefinery model. Biol Direct. 16(1):308- 316.

Mahan, J.D., Turman, M.A., Mentser, M.I. (1997). Evaluation of hematuria, proteinuria, and hypertension in adolescents. Pediatr Clin North Am. 44:1573-1589.

Mahan, L.K., \& Escott-Stump, S. (2008). Krause's Food \& Nutrition Therapy. St. Louis (MO): Elsevier.

Malta, D., Petersen, K. S., Johnson, C., Trieu, K., Rae, S., Jefferson, K., ... \& Arcand, J. (2018). High sodium intake increases blood pressure and the risk of kidney disease. From the Science of Salt: A regularly updated systematic review of salt and health outcomes (August 2016 to March 2017). The Journal of Clinical Hypertension. 20(12):1654-1665.

Marques, F.Z., Nelson, E., Chu, P.Y., Horlock, D., Fiedler, A., Ziemann, M., Tan, J.K., Kuruppu, S., Rajapakse, N.W., El-Osta, A., Mackay, C.R., Kaye, D.M.M.D. (2016). High fiber diet and acetate supplementation change the gut microbiota and prevent the development of hypertension and heart failure in hypertensive mice. Circulation. 135: 964977.

Molyneux, P. (2004). The use of the stable free radical diphenylpicrylhydrazyl (DPPH) for estimating antioxidant activity. Songklanakarin Journal of Science and Technology. 26(2):211-219

Mouritsen, O.G., Rhatigen, P., Llorens, J.L.P. (2018). World cuisine of seaweeds: science meets gastronomy. International Journal of Gastronomy and Food Science. 14: 55-65

Nufus, C., Abdullah, A., Nurjanah. (2019). Characteristics of green seaweed salt as alternative salt for hypertensive patients. In IOP Conference Series: Earth and Environmental Science (Vol. 278, No. 1, p. 012050). IOP Publishing.

Nurjanah, Abdullah, A., Diachanty, S. (2020b). Characteristics of Turbinaria conoides and Padina minor as raw materials for healthy seaweed salt. Pharmacognosy Journal. 12(3): 624629.

Nurjanah, Abdullah, A., Fachrozan, R., Hidayat, T. (2018a). Characteristics of seaweed porridge Sargassum sp. and Eucheuma cottonii as raw materials for lip balm. In IOP Publishing IOP Conference Series: Earth and Environmental Science. https://iopscience.iop.org/article/10.1088/1755-1315/196/1/012018.

Nurjanah, Abdullah, A., Nufus, C. (2018c). Characteristics of Ulva Lactuca seaweed salt from Sekantong waters, West Nusa Tenggara for hypertensive patients. Indonesian Fisheries Processing Journal. 21(1):109-117. https://doi.org/10.17844/jphpi.v20i3.19819 
Nurjanah, Aprilia, B. E., Fransiskayana, A., Rahmawati, M., Nurhayati, T. (2018b). Senyawa bioaktif rumput laut dan ampas teh sebagai antibakteri dalam formula masker wajah. Indonesian Fisheries Processing Journal. 20: 305-318. https://doi.org/10.17844/jphpi.v21i2.23086.

Nurjanah, Fauziyah, S., Abdullah, A. (2019c). Karakteristik bubur rumput laut Eucheuma cottonii dan Turbinaria conoides sebagai bahan baku masker peel off. Indonesian Fisheries Processing Journal. 22: 391-402. https://doi.org/10.17844/jphpi.v22i2.27893.

Nurjanah, Jacoeb AM, Ramlan, Abdullah A. (2020b). Penambahan genjer (Limnocharis flava) pada pembuatan garam rumput laut hijau untuk penderita hipertensi. Jurnal Pengolahan Hasil Perikanan Indonesia. 23(3): 459-469.

Nurjanah, Jacoeb, A. M., Bestari, E., Seulalae, A. V. (2020a). Karakteristik bubur rumput laut Gracilaria verrucosa dan Turbinaria conoides sebagai bahan baku body lotion. Jurnal Akuatek. 1: 73-83. https://doi.org/10.24198/akuatek.v1i2.29945.

Nurjanah, Luthfiyana, N., Hidayat, T., Nurilmala, M., Anwar, E. 2019a. Utilization of seaweed porridge Sargassum sp. and Eucheuma cottonii as cosmetic in protecting skin. In IOP Conf. Series: Earth and Environmental Science; 2018 Oct 9-10; Bogor, Indonesia: The 3rd EIW.

Nurjanah, Nurilmala M, Anwar, E., Luthfiyana, N., Hidayat, T. (2017). Identification of bioactive compounds of seaweed Sargassum sp. and Eucheuma cottonii doty as a raw sunscreen cream. Proceedings of the Pakistan Academy of Sciences: Pakistan Academy of Sciences B. Life and Environmental Sciences. 54: 311-318.

Nurjanah, Nurilmala, M., Abdullah, A., Seulalae, A. V., Fauzan, R. (2021). Characteristics of Eucheuma denticulatum and Turbinaria conoides porridge as body lotion materials. 17(4): 1521-1536.

Nurjanah, Nurilmala, M., Hidayat, T., Sudirdjo, F. (2016). Characteristics of seaweed as raw materials for cosmetics. Aquatic Procedia. 7: 177-180. https://doi.org/10.1016/j.aqpro.2016.07.024.

Nurjanah, Suwandi, R., Anwar, E., Maharany, F., Hidayat, T. (2019b). Characterization and formulation of sunscreen from seaweed Padina australis and Euchema cottonii slurry. In IOP Conference Series Earth Environmental Sciences. https://iopscience.iop.org/article/10.1088/1755-1315/404/1/012051.

Peñalver, R., Lorenzo, J. M., Ros, G., Amarowicz, R., Pateiro, M., Nieto, G. (2020). Seaweeds as a Functional Ingredient for a Healthy Diet. Marine Drugs. 18(6): 301.

Perez, M.J., Falque, E., Dominguez, H. (2016). Antimicrobial activity of compounds from marine seaweed-a review. Marine Drugs. 14(52):1-38. 
Perez, V., \& Chang, E. T. (2014). Sodium-to-Potassium Ratio and Blood Pressure, Hypertension, and Related Factors. Advances in Nutrition. 5(6): 712-741.

Ross, R. (1999). Atherosclerosis: an inflammatory disease. N Eng J Med. 340:115-126

Sari, D, M., Anwar, E., Nurjanah, Arifianti, A. E. (2019). Antioxidant and tyrosinase inhibitor activities of ethanol extracts of brown seaweed (Turbinaria conoides) as lightening ingredient. Pharmacognosy J. 11(2): 279-282. doi:10.5530/pj.2019.11.58.

Venugopal, V. (2008). Marine Products for Healthcare: Functional and Bioactive Nutraceutical Compounds from the Ocean. Florida: CRC Press.

Wakida, F.T., Lara-Ruiz, D., Temores-Pen, J., Rodriguez-Ventura, J.G., Diaz, C., Garcia-Flores, J.G. (2008). Heavy metals in sediments of the Tecate River. Mexico. Environmental Earth Sciences. 54, 637-642.

World Health Organization. (2012). Potassium intake for Adults and Children. Geneva. World Health Organization.

World Health Organization. (2012). Sodium intake for adults and children. Geneva. World Health Organization.

World Health Organization. (2013). Measure your blood, reduce your risk. Geneva(CHE): World Health Organization.

World Health Organization. (2015). World health statistic report 2015. Geneva(CHE): World Health Organization.

Submitted: $\quad 09 / 01 / 2021$

Revised: $\quad 24 / 07 / 2021$

Accepted: $\quad 21 / 08 / 2021$

DOI: $\quad 10.48129 / \mathrm{kjs} .11807$ 